\title{
The Characterization and Quality of 14 Accessions of Robusta Coffee
}

\author{
Budi Martono* and Eko Heri Purwanto \\ Indonesian Industrial and Beverages Crops Research Institute, Indonesian Agency for Agricultural \\ Research and Development, Sukabumi, West Java, Indonesia
}

\begin{abstract}
To produce superior varieties, gene sources of high diversity are needed. The study was intended to reveal the diversity of qualitative and quantitative characters and the quality of Robusta coffee germplasm. The study conducted at Pakuwon Experimental Garden, Sukabumi Indonesia, used 14 accessions of Robusta coffee grown by a single stem system. The observed characteristics were qualitative and quantitative characteristics, caffeine content, and cup quality. The data were analyzed descriptively and grouped by cluster analysis using the PBSTAT program. The results revealed variations in the angle of insertion of primary branches, stipule shape, immature leaf color, leaf shape, leaf apex shape, young shoot color, mature leaf color, ripe fruit color, and fruit shape. The number of bunches/branch is the characteristic of the highest variation coefficient. Eleven accessions had cupping scores between 80 and 86 with a caffeine content of $1.39-2.06 \%$. The accession B4-17-1 had the lowest yield, but its final cupping test score was the highest. At the dissimilarity coefficient of $0.25,14$ accessions of Robusta coffee are divided into two large groups, while at the dissimilarity coefficient of 0.15 they consist of four groups.
\end{abstract}

\section{Introduction}

Indonesia is one of the largest coffee exporting countries in the world. The volume of coffee exports in the last ten years has fluctuated, but it tends to decline with an average growth rate of $-1.89 \%$ per year. In 2008 the volume of Indonesian coffee exports was 468,749 tons with an export value of 991,458 million US dollars, in 2018 it decreased to 279,961 tons with an export value of 815,933 million US dollars. The area of coffee plantations in Indonesia reaches 1,252,825 hectares. Robusta coffee in smallholder plantations dominates Indonesian coffee production, reaching $68.65 \%$ and the remaining $27.98 \%$ is Arabica coffee [1].

Coffee production by small farmers is still low at $601.26 \mathrm{~kg} / \mathrm{ha} / \mathrm{year}$, which is very low compared to the potential of superior varieties which have yield potential of up to 3.31 tons/ha/year. The low production of small farmers' coffee is due to less intensive plant maintenance, pest/disease attacks, old plant age, and the farmers have not fully used recommended clones. One of the ways that can be done to increase the production and the

* Corresponding author: budimartono@hotmail.com 
quality of Robusta coffee is to use superior varieties. Superior varieties can be engineered through crosses followed by a series of selection and evaluation processes. The selection will be effective if the selected population has a wide genetic diversity [2]. The progress of breeding and selection is highly dependent on the potential and availability of sources of genetic diversity.

Germplasm as a genetic source containing superior traits or genes needed in engineering new high-yielding varieties needs to be characterized and evaluated. Characterization was carried out on both qualitative and quantitative characters, while the evaluation is aimed to find out more about the potential yield and quality and adaptability of an accession, especially to the biotic and abiotic environment. In Robusta coffee, quantitative traits can be used to determine the level of yield obtained [3]. These characters include the number of secondary branches, weight of 100 pieces, length of grain seeds, length of rice seeds, and weight of 100 grains of rice [4], plant height, stem diameter, number of productive branches, and number of bunches per plant [5].

The Indonesian Industrial and Beverage Crops Research Institute has collected Robusta coffee germplasm obtained from several central areas of coffee production such as East Lampung, South Lampung, and West Java [6]. The existing germplasm collection is expected to contain certain genes that are superior and unique for certain traits, such as high yield stability, high cup quality, pest resistance and environmental stress tolerance. The existence of genetic diversity of Robusta coffee can be disclosed by observing its qualitative and quantitative characters. The information on the diversity of germplasm is useful for maximizing the process of selecting parents in the assembly of varieties through crosses. The objective of this study is to reveal the diversity of Robusta coffee germplasm based on qualitative and quantitative characters and bean quality.

\section{Materials and methods}

This study was conducted at Pakuwon Experimental Garden and Integrated Laboratory of Indonesian Industrial and Beverage Crops Research Institute (IIBCRI), Sukabumi, from 2019 to 2020 .

\subsection{Materials}

The materials used were 14 accessions of Robusta coffee aged 7-8 years, namely B1-17-3, B1-20-2, B1-20-6, B2-1-1, B2-1-6, B2-1-7, B2-1-8, B2-1-9, B2-2-9, B2-2-10, B2-5-4, B2$8-2$, B2-12-1, and B4-17-1. Each accession was planted solitarily side by side with other accessions, the spacing used was $2.5 \times 2.5 \mathrm{~m}$ using a gliricidea shade with a spacing of $4 \times$ $6 \mathrm{~m}$. Plants were maintained with a single stem system using a single stage formed in the second year after planting with a plant height of $\pm 130 \mathrm{~cm}$. The shades of gliricidea are trimmed by $50 \%$ in the rainy season to reduce air humidity and to minimize pest and disease attacks. Plant maintenance activities include weeding, fertilizing, pruning, and controlling pest organisms. Fertilization is carried out according to the recommended dose i.e $150 \mathrm{~g}$ Urea, $60 \mathrm{~g}$ TSP, and $120 \mathrm{~g} \mathrm{KCl}$ per tree, 2 applications per year, at the beginning and the end of the rainy season. Fertilization is done by making a circular trench of trees as deep as $2-5 \mathrm{~cm}$ with the distance from the trunk $(30-40 \mathrm{~cm})$. The addition of organic in the soil was done by adding compost from goat manure as much as $1 \mathrm{~kg} /$ tree / year by spreading. Pest and disease control is adjusted to the conditions of the coffee plant in the field. Weeding is done every 2-3 months, while pruning is done every 2 months [7]. The testing of caffeine content and cup quality was done by means of naturally processed coffee beans which were roasted at a medium level, then processed into ground coffee. 


\subsection{Qualitative and quantitative characters}

The study was carried out during 2019 and 2020 at Pakuwon Experimental Garden, Sukabumi Indonesia with latosol soil type, climate type B according to Schmidt \& Ferguson (1951), and an altitude of $450 \mathrm{~m}$ above sea level. The observations were carried out using direct observation of fruit and leaf characters with reference to coffee descriptors [8]. The data collected included angle of insertion of primary branches, stipule shape, qualitative character of leaves and fruit, fruit yield per tree, stem circumference, number of fruits per bunch, number of bunches per branch, distance of bunches per branch, leaf length, leaf width, and leaf stalk length. Coffee harvesting was carried out on red fruit for 2 consecutive years of production by calculating the yield of ripe fruit per tree.

\subsection{Caffeine content}

The analysis of caffeine content in coffee beans was carried out using UV-Vis spectrophotometry in the Indonesian Industrial and Beverage Crops Research Institute integrated laboratory. The isolation of caffeine from coffee bean powder samples was done using $\mathrm{CaCO} 3$ and chloroform, then it was evaporated using a rotary evaporator. The determination of caffeine content was done by comparing the absorbance of the caffeine extract solution with a standard solution of caffeine using a UV-Vis spectrophotometer at a wavelength of $281 \mathrm{~nm}$ [9].

\subsection{Cupping test}

Cupping test of coffee beans was carried out at the Indonesian Coffee and Cocoa Research Institute Laboratory Jember referring to the standards and protocols for fine Robusta compiled by the Uganda Coffee Development Authority and the Coffee Quality Institute [10]. The assessment of the sensory attributes of coffee was carried out by 3 expert panelists. The cup quality components observed included the attributes of smell/aroma when brewed (aroma), taste on the tongue (flavor), the taste left in the mouth (aftertaste), salty/acid, bitter/sweet taste, viscosity (body), uniformity of taste from each cup (uniformity), aspects of taste balance (balance), general taste impression (clean cup), and overall taste aspects. Panelists assessed each sensory attribute with a score of 6.00 to 6.75 (good); 7.00 to 7.75 (very good); 8.00 to 8.75 (excellent), and 9.00 to 10.00 (outstanding). The final score was obtained by adding up the scores for each attribute. If the value is $\geq 80$ on a scale of 100 based on the cupping test, it can be categorized as fine robusta coffee.

\subsection{Data analysis}

The observational data were analyzed descriptively using Minitab 16 software by calculating the average value, standard deviation, variation coefficient, minimum value, and maximum value [11]. Cluster analysis was performed with the unweighted-pair group method with arithmetic means (UPGMA), and a dendrogram was generated by using PBSTAT 3.1 online software.

\section{Results and discussion}

\subsection{Diversity of qualitative characters}

The results of observations on 14 accessions of Robusta coffee showed that the qualitative diversity was seen in the angle of insertion of primary branches, stipule shape, immature leaf color, leaf shape, leaf apex shape, young shoot color, mature leaf color, ripe fruit color, and fruit shape. All accessions had the same petiole color (green) and the present of ribs on the fruit. 
Table 1. Performance of the qualitative characteristics of the 14 accessions of Robusta coffee

\begin{tabular}{|c|c|c|c|c|c|c|c|c|c|c|c|c|}
\hline \multirow[t]{2}{*}{ No. } & \multirow{2}{*}{$\begin{array}{c}\text { Accessi } \\
\text {-on }\end{array}$} & \multicolumn{11}{|c|}{ Parameters of observations } \\
\hline & & AIPB & SS & ILC & LS & LAS & LPC & YSC & MLC & FC & FS & FR \\
\hline 1. & B1-17-3 & Semi-erect & Triangular & Greenish & Ovalis-oblongus & Apiculate & Green & Brownish & Green & Orange-red & Roundish & Present \\
\hline 2. & B1-20-2 & Semi-erect & Triangular & Greenish & Ovalis-oblongus & Apiculate & Green & Brownish & Green & Orange-red & Roundish & Present \\
\hline 3. & B1-20-6 & Horizontal & Triangular & Green & Oblongus & Apiculate & Green & Brownish & \begin{tabular}{|l|} 
Dark \\
Green \\
\end{tabular} & Red & Roundish & Present \\
\hline 4. & B2-1-1 & Semi-erect & Triangular & Greenish & Ovalis-oblongus & Acuminate & Green & Brownish & Green & Orange-red & Roundish & Present \\
\hline 5. & B2-1-6 & Semi-erect & Triangular & Greenish & Ovalis-oblongus & Apiculate & Green & Brownish & Green & Orange-red & Roundish & Present \\
\hline 6. & B2-1-7 & Semi-erect & Triangular & Greenish & Oblongus & Apiculate & Green & $\begin{array}{l}\text { Brownish } \\
\text { Green }\end{array}$ & Green & Orange-red & Roundish & Present \\
\hline 7. & B2-1-8 & Horizontal & Triangular & Greenish & Ovalis-oblongus & Apiculate & Green & $\begin{array}{l}\text { Brownish } \\
\text { Green }\end{array}$ & Green & Orange-red & Roundish & Present \\
\hline 8. & B2-1-9 & Semi-erect & Triangular & Greenish & Ovalis-oblongus & Acuminate & Green & $\begin{array}{l}\text { Brownish } \\
\text { Green }\end{array}$ & Green & Orange-red & Roundish & Present \\
\hline 9. & B2-2-9 & Semi-erect & Round & Greenish & Ovalis-oblongus & Apiculate & Green & $\begin{array}{l}\text { Brownish } \\
\text { Green }\end{array}$ & Green & Orange-red & Oblong & Present \\
\hline 10. & B2-2-10 & Drooping & Deltate & Greenish & Oblongus & Acuminate & Green & $\begin{array}{l}\text { Brownish } \\
\text { Green }\end{array}$ & Green & Red & Roundish & Present \\
\hline 11. & B2-5-4 & Semi-erect & Triangular & Greenish & Oblongus & Apiculate & Green & Brownish & Green & Orange-red & Roundish & Present \\
\hline 12. & B2-8-2 & Semi-erect & Triangular & Greenish & Ovalis-oblongus & Apiculate & Green & $\begin{array}{l}\text { Brownish } \\
\text { Green }\end{array}$ & Green & Orange-red & Roundish & Present \\
\hline 13. & B2-12-1 & Semi-erect & Triangular & Greenish & Ovalis-oblongus & Apiculate & Green & $\begin{array}{l}\text { Brownish } \\
\text { Green }\end{array}$ & Green & Orange-red & Roundish & Present \\
\hline 14. & B4-17-1 & Semi-erect & Deltate & Greenish & Ovalis-oblongus & Apiculate & Green & Brownish & Green & Orange-red & Oblong & Present \\
\hline \multicolumn{2}{|c|}{ Percentage (\%) } & $\begin{array}{l}\text { Semi- } \\
\text { erect: } \\
78.57 \\
\text { Horizontal } \\
: 14.29 \% \\
\text { Drooping: } \\
7.14 \%\end{array}$ & $\begin{array}{l}\text { Triangular: } \\
78.57 \% \\
\text { Round: } \\
7.14 \% \\
\text { Deltate: } \\
14.29 \%\end{array}$ & $\begin{array}{l}\text { Greenish: } \\
92.86 \% \% \\
\text { Green: } \\
7.14 \%\end{array}$ & 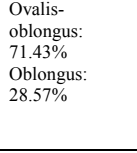 & $\begin{array}{l}\text { Apiculate: } \\
78.57 \% \\
\text { Acuminate: } \\
21.43 \%\end{array}$ & $\begin{array}{l}\text { Green: } \\
100 \%\end{array}$ & $\begin{array}{l}\text { Brownish: } \\
50 \% \\
\text { Brownish } \\
\text { Green: } \\
50 \%\end{array}$ & $\begin{array}{l}\text { Green: } \\
92.86 \% \\
\text { Dark } \\
\text { Green: } \\
7.14 \%\end{array}$ & \begin{tabular}{|l} 
Orange-red: \\
$85,71 \%$ \\
Red: \\
$14.29 \%$
\end{tabular} & $\begin{array}{l}\text { Roundish: } \\
85,71 \% \\
\text { Oblong: } \\
14,29 \%\end{array}$ & $\begin{array}{l}\text { Present: } \\
100 \%\end{array}$ \\
\hline
\end{tabular}

Remarks : AIPB: Angle of insertion of primary branches; SS : Stipule shape; ILC : Immature leaf color; LS : Leaf shape; LAS : Leaf apex shape; LPC : Leaf petiole color; YSC: Young shoot color; MLC : Mature leaf color; FC: Fruit color; FS : Fruit shape; FR: Absence/presence of fruit ribs. 
All accessions showed diversity in the angle of insertion of primary branches which was dominated by semi-erect forms (78.57\%), except for B1-20-8 and B2-1-8 (horizontal) and B22-10 (drooping). The color of young leaves was dominated by greenish by $92.86 \%$, except for B1-20-6 which was green. Accessions B1-20-6, B2-1-7, B2-2-10, and B2-5-4 had an oblongus leaf shape, while the other ten accessions were ovalis-oblongus. The shape of the leaf tip is divided into two, namely acuminate and apiculate. The acuminate forms were found in B2-11, B2-1-9, and B2-2-10. Seven accessions had a brownish shoot color, while the other seven accessions were brownish green. All accessions had mature leaf of green color except B1-206 which was dark green. The color of the fruit was dominated by orange-red, only one accession was red (B1-20-6). The oblong fruit shape was owned by accessions B-2-1-9 and B4-17-1, while the other accessions were roundish.

\subsection{Diversity of quantitative characteristics}

The results of the data analysis showed that the coefficient of variation of the agronomy and fruit quantitative characteristics observed ranged from 8.20 to $26.51 \%$ (Table 2 and Table 3 ). The value of the coefficient of variation can be used to estimate the level of character diversity of a population, namely the variation coefficient value $>25 \%$ classified as high variation [12] whereas the diversity is classified as low if the variation coefficient value ranges from 0 to $25 \%$ [13]. Based on these categories, the number of bunches/branch had a high level of diversity (26.51\%). Stem diameter, number of fruit/bunch, distance between bunches, weight of 100 fruits, leaf length, leaf width, petiole length, production, caffeine content, fruit length, fruit width, and fruit thickness were characteristics with a low level of diversity, meaning that all the observed accessions have uniform values for all six characteristics. Low coefficient of diversity in leaf length, leaf width, and petiole length had also been previously reported [14].

Table 2. Performance of the agronomy quantitative characteristics of the 14 accessions of Robusta coffee

\begin{tabular}{|l|l|c|c|c|c|c|c|c|}
\hline & & \multicolumn{7}{|c|}{ Parameters of observations } \\
\cline { 3 - 9 } No. & Accession & $\begin{array}{c}\text { Trunk } \\
\text { diameter } \\
(\mathrm{cm})\end{array}$ & $\begin{array}{c}\text { Number of } \\
\text { fruits } \\
\text { /bunch }\end{array}$ & $\begin{array}{c}\text { Number } \\
\text { of } \\
\text { bunches } \\
\text { /Branch }\end{array}$ & $\begin{array}{c}\text { Distance } \\
\text { between } \\
\text { bunches } \\
(\mathrm{cm})\end{array}$ & $\begin{array}{c}\text { Leaf } \\
\text { length } \\
(\mathrm{cm})\end{array}$ & $\begin{array}{c}\text { Leaf } \\
\text { width }\end{array}$ & $\begin{array}{c}\text { Petiole } \\
\text { length } \\
(\mathrm{cm})\end{array}$ \\
\hline 1. & B1-17-3 & 44 & 11.90 & 9.10 & 6.77 & 22.70 & 10.46 & 1.50 \\
\hline 2. & B1-20-2 & 30 & 21.50 & 6.55 & 7.09 & 25.70 & 10.82 & 1.46 \\
\hline 3. & B1-20-6 & 29 & 15.87 & 6.70 & 6.27 & 23.40 & 8.54 & 1.50 \\
\hline 4. & B2-1-1 & 36 & 19.82 & 3.82 & 8.64 & 23.40 & 10.22 & 1.78 \\
\hline 5. & B2-1-6 & 37 & 21.60 & 5.25 & 8.18 & 18,12 & 8.62 & 1.16 \\
\hline 6. & B2-1-7 & 30 & 19.36 & 5.10 & 7.09 & 21.40 & 8.42 & 1.56 \\
\hline 7. & B2-1-8 & 39 & 14.64 & 4.00 & 7.00 & 22.10 & 9.70 & 1.52 \\
\hline 8. & B2-1-9 & 35 & 16.57 & 5.10 & 6.59 & 22.59 & 9.29 & 1.50 \\
\hline 9. & B2-2-9 & 29 & 15.57 & 8.14 & 6.29 & 23.10 & 9.96 & 1.22 \\
\hline 10. & B2-2-10 & 23 & 13.83 & 6.70 & 7.50 & 25.10 & 9.22 & 1.52 \\
\hline 11. & B2-5-4 & 32 & 15.07 & 8.38 & 6.09 & 23.50 & 8.96 & 1.65 \\
\hline 12. & B2-8-2 & 26 & 12.38 & 4.70 & 6.23 & 20.54 & 8.50 & 1.40 \\
\hline 13. & B2-12-1 & 30 & 18.50 & 5.50 & 7.08 & 19.60 & 9.20 & 1.44 \\
\hline 14. & B4-17-1 & 25 & 11.17 & 6.67 & 7.17 & 19.22 & 9.14 & 1.20 \\
\hline Average \pm SD & $33.79 \pm 5.81$ & $16.27 \pm 3.44$ & $6.12 \pm 1.62$ & $7.00 \pm 0.74$ & $22.18 \pm 2.19$ & $9.36 \pm 0.77$ & $1.46 \pm 0.17$ \\
\hline CV (\%) & 18.27 & 21.15 & 26.51 & 10.53 & 9.86 & 8.20 & 11.72 \\
\hline Minimum value & 23.00 & 11.17 & 3.82 & 6.09 & 18.12 & 8.42 & 1.16 \\
\hline Maximum value & 44.00 & 21.60 & 9.10 & 8.64 & 25.70 & 10.82 & 1.78 \\
\hline
\end{tabular}

Remarks: $\mathrm{SD}=$ Standard Deviation; $\mathrm{CV}=$ Coefficient of Variation 
Robusta coffee production has a close correlation, among others, with the characteristics of stem circumference, number of fruit per bunch, leaf length, weight of 100 fresh fruit, fruit length, and fruit thickness [3]. The seven characteristics were taken into consideration in selecting high production clones with a coefficient of variation ranging from 5.22 to $21.15 \%$. The production data for 2 consecutive years are presented in Table 3 . Based on the observations, it is known that the production of the 14 accessions tested ranged from 3.99 to $8.06 \mathrm{~kg}$ per tree with an average population of $5.81 \mathrm{~kg}$ per tree. The response of each accession showed that 6 accessions had above average productivity, namely B2-1-8 $(8.06 \mathrm{~kg}$ per tree), B1-17-3, B2-1-1, B2-1-6, B2-2- 9, and B2-5-4 which ranged from 6.07 to $7.27 \mathrm{~kg}$ per tree. Most of the accessions, namely 8 accessions had lower productivity than the general average of 3.99 to $5.70 \mathrm{~kg} /$ tree. Meanwhile, the highest production was found in accessions per tree or 2,58 $\mathrm{kg}$ per ha of market coffee with the assumption that the total plant population in 1 ha was 1,600 trees and the yield was $20 \%$.

The Robusta coffee germplasm collected came from seeds so that there was diversity in the characteristic of fruit weight per tree with a variation coefficient value of $19.72 \%$. This is because Robusta coffee is self-incompatible, so it tends to be cross-pollinated $[15,16,17]$ that causes genetic diversity in its offspring. Thus, in its cultivation it must be planted side by side with other coffee plants of different types. Based on the data on Table 3 and Table 4, there are 3 accessions with the highest average production and had cupping scores higher than 80 respectively B2-1-8 (8.06 kg/tree), B2-2-9 (7.27 kg/tree), and B2-1-1 (6.70 kg/tree). The three accessions need to be observed further by observing the flowering time and fertilization pattern of each clone. The three accessions could be combined into one suitable clone composition if the clones had the same flowering time and fertilization pattern.

Table 3. Production, caffeine content, and fruit quantitative characteristics of 14 accessions of Robusta coffee

\begin{tabular}{|c|c|c|c|c|c|c|c|}
\hline \multirow[b]{2}{*}{ No. } & \multirow[b]{2}{*}{ Accession } & \multicolumn{6}{|c|}{ Parameters of observations } \\
\hline & & $\begin{array}{l}\text { Production } \\
\quad(\mathrm{kg})\end{array}$ & $\begin{array}{c}\text { Caffeine } \\
\text { content } \\
(\%)\end{array}$ & $\begin{array}{l}\text { Weight of } \\
100 \text { fresh } \\
\text { fruits } \\
(\mathrm{g})\end{array}$ & $\begin{array}{l}\text { Fruit } \\
\text { length } \\
(\mathrm{cm})\end{array}$ & $\begin{array}{l}\text { Fruit width } \\
(\mathrm{cm})\end{array}$ & $\begin{array}{c}\text { Thickness } \\
\text { of fruit } \\
\text { (cm) }\end{array}$ \\
\hline 1. & B1-17-3 & 6.83 & 1.82 & 224.74 & 17.23 & 16.21 & 13.71 \\
\hline 2. & B1-20-2 & 5.61 & 1.93 & 195.17 & 16.53 & 15.21 & 13.08 \\
\hline 3. & B1-20-6 & 4.09 & 1.65 & 138.95 & 13.67 & 14.36 & 11.85 \\
\hline 4. & B2-1-1 & 6.70 & 1.70 & 205.78 & 15.95 & 15.90 & 13.61 \\
\hline 5. & B2-1-6 & 6.07 & 1.80 & 177.03 & 16.14 & 14.45 & 12.47 \\
\hline 6. & B2-1-7 & 5.70 & 1.72 & 176.25 & 17.63 & 16.37 & 13.79 \\
\hline 7. & B2-1-8 & 8.06 & 1.94 & 214.28 & 16.70 & 16.45 & 14.18 \\
\hline 8. & B2-1-9 & 5.15 & 1.54 & 168.75 & 17.21 & 14.56 & 12.09 \\
\hline 9. & B2-2-9 & 7.27 & 2.06 & 196.58 & 18.54 & 13.84 & 13.15 \\
\hline 10. & B2-2-10 & 5.08 & 1.53 & 196.54 & 16.25 & 15.88 & 12.85 \\
\hline 11. & B2-5-4 & 6.17 & 1.39 & 165.88 & 16.05 & 14.86 & 12.87 \\
\hline 12. & B2-8-2 & 5.28 & 1.87 & 150.18 & 16.19 & 14.58 & 12.82 \\
\hline 13. & B2-12-1 & 5.30 & 1.76 & 206.33 & 15.72 & 14.33 & 12.90 \\
\hline 14. & B4-17-1 & 3.99 & 1.47 & 232.67 & 19.20 & 15.51 & 13.86 \\
\hline \multicolumn{2}{|c|}{ Average \pm SD } & $5.81 \pm 1.15$ & $1.73 \pm 0.20$ & $189.22 \pm 27.48$ & $16.64 \pm 1.33$ & $15.18 \pm 0.87$ & $\begin{array}{l}13.09 \\
\pm 0.68\end{array}$ \\
\hline \multicolumn{2}{|c|}{ CV (\%) } & 19.72 & 11.28 & 14.52 & 7.98 & 5.71 & 5.22 \\
\hline \multicolumn{2}{|c|}{ Minimum value } & 3.99 & 1.39 & 138.95 & 13.67 & 13.84 & 11.85 \\
\hline \multicolumn{2}{|c|}{ Maximum value } & 8.06 & 2.06 & 232.67 & 19.20 & 16.45 & 44.00 \\
\hline
\end{tabular}

Remarks: SD = Standard Deviation; $\mathrm{CV}=$ Coefficient of Variation 


\subsection{Caffeine content}

The data on caffeine content of the 14 accessions of Robusta coffee are presented in Table 3. Seven accessions have caffeine content ranging from 1.76 to $2.06 \%$ or higher than the population average (1.73\%). The other accessions, namely B1-20-6, B2-1-1, B2-1-7, B2-19, B2-2-10, B2-5-4, and B4-17-1 (1.39-1.65\%) have lower caffeine content. This value corresponds to the range of the caffeine content of Robusta coffee between 0.9 and $3.8 \%$, as reported $[18,19,20]$. The existence of the diversity of caffeine content between accessions indicated by a variation coefficient of $11.28 \%$ provides an opportunity for breeders to select Robusta coffee based on the characteristics of low caffeine content. Based on the observational data, the accessions that show the lowest caffeine content is B2-5-4 (1.39\%). The highest caffeine content is shown by accessions B2-2-9 of 2.06\%. The diversity of caffeine content in coffee beans is influenced by many factors, including the variety [21], the light intensity [22], the altitude and the temperature [23,24,25].

The caffeine in coffee beans causes a bitter taste [26]. The bitter taste if accumulated in excess will be able to affect the aftertaste attributes and the overall taste of coffee [27]. The caffeine (1,3,7 trimethylxanthine) is a natural alkaloid that can stimulate the central nervous system, muscles, heart, and circular system of the human body. The caffeine can improve alertness, learning capacity and exercise performance when consumed in moderation $[28,29,30]$.

\subsection{Cluster analysis}

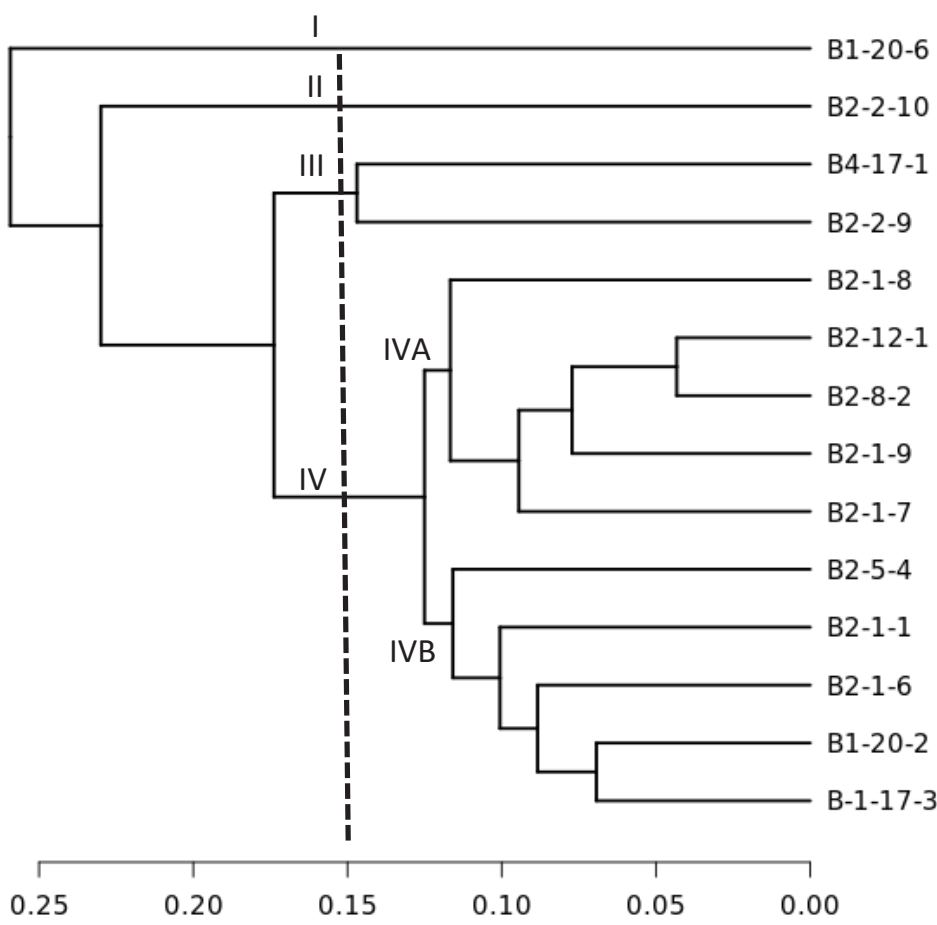

Distance of dissimilarity

Fig. 1. Dendogram of 14 accessions of Robusta coffee based on 24 qualitative and quantitative characteristics. 
The results of the analysis of the grouping of the 14 accessions of Robusta coffee based on the 24 qualitative and quantitative characteristics are shown in Figure 1. At the dissimilarity coefficient of 0.25 , the dendogram is divided into two large groups. Group I consisted of one clone, namely B-1-20-6. The second group consisted of thirteen accessions, namely B2-2-10, B-4-17-1, B2-2-9, B2-1-8, B2-12-1, B2-8-2, B2-1- 9, B2-1-7, B2-5-4, B2-1-1, B2-1-6, B1-20-2, and B1-17-3. The distinguishing characters between the two groups were mainly on the color of the immature leaves and the color of the mature leaves. The accessions in group I had green immature leaves and dark green mature leaves. The accessions in group II had greenish immature leaves and green mature leaves.

The fourteen accessions with a coefficient of dissimilarity of 0.15 were divided into four groups. Groups I and II each consisted of 1 accession, namely B 1-20-6 in group I and B22-10 in group II. Accessions B2-2-10 formed its own group mainly because of the difference in Angle of insertion of primary branches. Accessions B2-2-10 had drooping branches. Group III consisted of B4-17-1 and B2-2-9, the two accessions formed their own group among other accessions mainly because of differences in fruit shape. B4-17-1 and B2-2-9 had a characteristic oblong fruit shape. Group IV was divided into two sub groups. Sub-group IVA consisted of 5 accessions, namely B2-1-8, B2-12-1, B2-8-2, B2-1-9, and B2-1-7, sub-group IVB consisted of 5 accessions (B2-5 -4, B2-1-1, B2-1-6, B1-20-3, and B1-17-3).

\subsection{Cup quality}

The cup quality or high taste is one of the important criteria to be considered in selecting coffee plants. The results of the evaluation of the sensory quality of Robusta coffee germplasm are presented in Table 4. The cupping test showed that the 14 accessions of the Robusta coffee had an average cupping score of 82.32 with a minimum cupping score of 77.75 and a maximum of 86.00. The results of this study revealed the information from one accession, namely B4-17-1 which had the best cup quality with the highest cupping score of 86.00. The lowest cupping score was indicated by accession B1-20-2, namely 77.75. Three accessions of Robusta coffee had cupping scores below 80 . The other eleven accessions, namely B2-1-1, B2-1-6, B2-1-7, B2-1-8, B2-1-9, B2-2- 9, B2-2-10, B2-5-4, B2-8-2, B2-121 , and $\mathrm{B} 4-17-1$ had cupping scores higher than 80 so that they can be categorized as fine Robusta which is synonymous with coffee specialty for Arabica coffee. The average production of the eleven accessions of Robusta coffee in a period of 2 years ranged from 3.99 to $8.06 \mathrm{~kg} /$ tree. The highest average production was found in the accessions B2-1-8 of $8.06 \mathrm{~kg} /$ tree with a final cup quality score of 83.50 . The accession of B4-17-1 had the lowest coffee fruit production of $3.99 \mathrm{~kg}$, however this accession had the advantage of having the highest final score of the cupping test, which was 86.00. There are many factors affecting the taste of coffee, such as clones and light intensity [21].

The clones affect the resulting flavor profile. The accession B4-17-1 had the best aroma intensity and quality among the accessions tested. Among the evaluated accessions, the accessions B2-5-4, B2-8-2, B2-12-1, and B4-17-1 had the highest scores of aroma, flavor, aftertaste, salt/acid, bitter/sweet, body, balance, and overall with excellent intensity ranging from 8.00 to 8.50 . The clones B2-5-4, B2-8-2, and B2-12-1 had sensory attributes with the same score with a final score of 84.00 ; The same score was also shown by the accessions B2-1-7 and B2-2-9 with a final score of 82.75. 
Table 4. The results of cup test analysis of the 14 accessions of Robusta coffee

\begin{tabular}{|c|c|c|c|c|c|c|c|c|c|c|c|c|}
\hline \multirow[b]{2}{*}{ Accession } & \multicolumn{11}{|c|}{ Characteristics } & \multirow[b]{2}{*}{ Notes } \\
\hline & $\begin{array}{c}\text { Fragrancel } \\
\text { Aroma }\end{array}$ & Flavor & Aftertaste & Salt/Acid & $\begin{array}{l}\text { Bitter } \\
\text { /Sweet }\end{array}$ & Body & $\begin{array}{l}\text { Uniform } \\
\text { cups }\end{array}$ & Balance & $\begin{array}{l}\text { Clean } \\
\text { cups }\end{array}$ & Overal & $\begin{array}{l}\text { Final } \\
\text { score }\end{array}$ & \\
\hline B1-17-3 & 8.00 & 7.50 & 7.50 & 7.00 & 7.00 & 7.50 & 10.00 & 7.00 & 10.00 & 7.00 & 78.50 & Caramelly, Greenish \\
\hline B1-20-2 & 7.75 & 7.50 & 7.00 & 7.00 & 7.00 & 7.50 & 10.00 & 7.00 & 10.00 & 7.00 & 77.75 & $\begin{array}{l}\text { Caramelly, Nutty, Spicy, } \\
\text { Cereally }\end{array}$ \\
\hline B1-20-6 & 7.75 & 7.75 & 7.50 & 7.25 & 7.50 & 8.00 & 10.00 & 7.00 & 10.00 & 7.00 & 79.75 & $\begin{array}{l}\text { Caramelly, Nutty, Spicy, } \\
\text { Greenish, like Liberica }\end{array}$ \\
\hline B2-1-1 & 7.75 & 7.75 & 7.75 & 7.75 & 7.75 & 7.75 & 10.00 & 7.75 & 10.00 & 7.75 & 82.00 & Caramelly, Nutty, Spicy \\
\hline B2-1-6 & 8.00 & 7.75 & 7.75 & 7.75 & 7.75 & 8.00 & 10.00 & 7.75 & 10.00 & 8.00 & 82.75 & $\begin{array}{l}\text { Caramelly, Nutty, Spicy, } \\
\text { Brown sugar }\end{array}$ \\
\hline B2-1-7 & 7.75 & 8.00 & 8.00 & 7.00 & 8.00 & 8.00 & 10.00 & 8.00 & 10.00 & 8.00 & 82.75 & Caramelly, Greenish \\
\hline B2-1-8 & 8.00 & 8.00 & 8.00 & 7.75 & 7.75 & 8.00 & 10.00 & 8.00 & 10.00 & 8.00 & 83.50 & Caramelly, Greenish \\
\hline B2-1-9 & 8.00 & 7.75 & 7.75 & 7.75 & 7.75 & 7.75 & 10.00 & 7.75 & 10.00 & 8.00 & 82.50 & $\begin{array}{l}\text { Caramelly, Brown } \\
\text { sugar, Spicy, Sweet }\end{array}$ \\
\hline B2-2-9 & 7.75 & 8.00 & 8.00 & 7.00 & 8.00 & 8.00 & 10.00 & 8.00 & 10.00 & 8.00 & 82.75 & $\begin{array}{l}\text { Caramelly, Spicy, } \\
\text { Greenish }\end{array}$ \\
\hline B2-2-10 & 7.75 & 7.75 & 7.75 & 7.75 & 7.75 & 8.00 & 10.00 & 7.75 & 10.00 & 7.75 & 82.25 & $\begin{array}{l}\text { Brown sugar, } \\
\text { Chocolaty, Spicy }\end{array}$ \\
\hline B2-5-4 & 8.00 & 8.00 & 8.00 & 8.00 & 8.00 & 8.00 & 10.00 & 8.00 & 10.00 & 8.00 & 84.00 & $\begin{array}{l}\text { Milk Chocolaty, } \\
\text { Caramelly }\end{array}$ \\
\hline B2-8-2 & 8.00 & 8.00 & 8.00 & 8.00 & 8.00 & 8.00 & 10.00 & 8.00 & 10.00 & 8.00 & 84.00 & $\begin{array}{l}\text { Caramelly, Tropical } \\
\text { fruit aroma, greenish }\end{array}$ \\
\hline B2-12-1 & 8.00 & 8.00 & 8.00 & 8.00 & 8.00 & 8.00 & 10.00 & 8.00 & 10.00 & 8.00 & 84.00 & $\begin{array}{l}\text { Brown sugar, Tropical fruit } \\
\text { aroma, Caramelly, black tea }\end{array}$ \\
\hline B4-17-1 & 8.50 & 8.50 & 8.50 & 8.00 & 8.00 & 8.00 & 10.00 & 8.00 & 10.00 & 8.50 & 86.00 & $\begin{array}{l}\text { Caramelly, Brown } \\
\text { sugar, Vanilla, Pandan } \\
\text { fragrance }\end{array}$ \\
\hline Average & 7.93 & 7.82 & 7.82 & 7.57 & 7.73 & 7.89 & 10 & 7.71 & 10 & 7.79 & 82.32 & \\
\hline
\end{tabular}

Remarks: $6.00-6.75=$ Good $; 7.00-7.75=$ Very good $; 8.00-8.75=$ Excellent; $9.00-9.75=$ Outstanding. 
The character of the coffee aroma in general can reflect the taste of the coffee. Aroma includes fragrance (the smell of coffee when it is dry/powdered) and aroma (the smell when the coffee is brewed with hot water). The difference in the overall score of the accessions evaluated was not too significant, except for B1-17-3, B1-20-2, and B1-20-6 with a score of 7.00. Each of the evaluated accessions had specific pleasant flavors such as caramelly, nutty, spicy, cereally, chocolaty, vanilla, and pandan fragrance. The characteristic note taste of coffee brewing is generally caramelly. Greenish taste, which is a taste character such as leaves/grass/cincau caused by poor post-harvest handling as a result of the coffee not being completely dried during the drying process.

\section{Conclusion}

The diversity of qualitative characters can be seen in the angle of insertion of primary branches, stipule shape, young leaf color, leaf shape, leaf apex shape, immature leaf color, mature leaf color, ripe fruit color, and fruit shape. The number of bunches per branch is the characteristic with the greatest coefficient of variation. Fresh fruit production ranges from 3.99 to $8.06 \mathrm{~kg}$ per tree or an average of $5.81 \mathrm{~kg}$ per tree. Accession B4-17-1 had the lowest production but it had the highest final score of cupping test (86). Eleven accessions evaluated (B2-1-1, B2-1-6, B2-1-7, B2-1-8, B2-1-9, B2-2-9, B2-2-10, B2-5 -4, B2-8-2, B212-1, and $\mathrm{B} 4-17-1)$ had cupping scores higher than 80 with caffeine content ranging from 1.39 to $2.06 \%$. At the coefficient of dissimilarity of 0.25 , the dendogram was divided into two large groups. Based on 0.15 dissimilarity, Robusta coffee germplasm is divided into four groups.

\section{References}

1. Ditjenbun, Statistik Perkebunan Indonesia 2018-2020: Kopi, 77 (Kementan, Jakarta, 2019)

2. M. Syukur, S. Sujiprihati, R. Yunianti, Teknik Pemuliaan Tanaman, 348 (Penerbit Swadaya, Jakarta, 2012)

3. V.B. Sureshkumar, K.R. Nikhila, N.S. Prakash, K.V. Mohanan, J. AFF. 2(2), 98-104 (2013)

4. E. Randriani, Dani, C. Tresniawati, Syafaruddin, J. TIDP. 1(2), 109-116 (2014)

5. D. Rizki, B.R. Wijonarko, Purwanto, COMPOSIE: J. Ilmu Pertanian. 02(1), 11-16 (2020)

6. B. Martono, R.T. Setiyono, L.T.S. Udarno, Bunga Rampai Inovasi Teknologi Tanaman Kopi untuk Perkebunan Rakyat, 5-12 (2013)

7. P. Raharjo, Berkebun Kopi, 116 (Penerbit Penebar Swadaya, Jakarta, 2017)

8. IPGRI, Descriptors for Coffee (Coffea spp. and Psilanthus spp.), 38 (International Pant Genetic Resources Institute, Rome, 1996)

9. Elfariyanti, E. Silviana, M. Santika, Lantanida J. 8(1), 1-12 (2020)

10. A. Hetzel, Fine Robusta Standards and Protocols: A compilation of technical standards, evaluation procedures and reference materials for quality-differentiated Robusta coffee (CQI, Aliso Viejo, 2015)

11. A. Suparno, A.D. Nusantara, Perancangan Percobaan Aplikasi Minitab, SAS, dan CoStat dalam Analisis Data, 176 (Alfabeta, 2013)

12. R.D. Purwati, T.D.A. Anggraeni, H. Sudarno, Bul. Tanaman Tembakau, Serat, dan Minyak Industri. 7(2), 69-78 (2015) 
13. A.N. Nilasari, J.B.S. Heddy, T. Wardiyati, J. Produksi Tanaman. 1(1), 61-69 (2013)

14. S. Ramadiana, D. Hapsoro, Yusnita, Biodiversitas. 19(4), 1475-1481 (2018)

15. P. Cubry, F. de Bellis, D. Pot, P. Musoli, T. Leroy, Genetic Resources and Crop Evolution. 60(2), 483-501 (2013)

16. A. Hetzel, Fine Robusta standards and protocols. Uganda: Coffee Development Authority, (2015)

17. M.S. Moraes, A.L. Teixeira, A.R. Ramalho, M.C. Espíndula, M.A.G. Ferrão, R.B. Rocha, Genetics and Molecular Research. 17(1), 1-11 (2018).

18. Dani, C. Tresniawati, E. Randriani, Bul. RISTRI. 4(2), 139-144 (2013)

19. V.B. Sureshkumar, N.S. Prakash, K.V. Mohanan, Int. J. Plant Breed. Genet. 4, 30-35 (2010)

20. H. Ashihara, M. Kato, A. Crozier, Distribution, Biosynthesis and Catabolism of Methylxanthines in Plants In B.B. Fredholm (ed.), Methylxanthines, Handbook of Experimental Pharmacology 200 (C) Springer-Verlag Berlin Heidelberg, 2011)

21. J. Gaibor, D. Morales, W. Carrillo, Asian J. Crop Sci. (2020)

22. N.P. Erdiansyah, Yusianto, Pelita Perkebunan. 28(1), 14-22 (2012)

23. T. Joet, A. Laffargue, F. Descroix, S. Doulbeau, B. Bertrand, A. de Kochko, S. Dussert, Food Chem. 118, 693-701 (2010)

24. R.M. El-Abassy, P. Donfack, A. Materny, Food Chem. 126, 1443-1448 (2011)

25. C.S.G. Kitzberger, M.B. dos Santos Scholz, L.F.P. Pereira, L.G.E. Vieira, T. Sera, J.B.G.D. Silva, M. de Toledo Benassi, J. Food Compos. Anal. 30, 52-57 (2013)

26. Jue-Sheng Ong, Liang-Dar Hwang, V.W. Zhong, J. An, P. Gharahkhani, P.A.S. Breslin, M.J. Wright, D. A. Lawlor, J. Whitfield, S. MacGregor, N.G. Martin, M.C. Cornelis, Scientific Reports. 8, 16414 (2018)

27. M.T.L. Kreuml, D. Majchrzak, B. Ploederl, J. Koenig, Food Sci. Nutr. 1(4), 267-272 (2013)

28. L. Bresciani, L. Calani, R. Bruni, F. Brighenti, D. Del Rio, Food Res. Int. 61, 196-201 (2014)

29. M.J. Alomar, Int. J. Pharm. Pharmaceut. Sci. 8: 101-103 (2016)

30. A. Panusa, R. Petrucci, R. Lavecchia, A. Zuorro, Food Res. Int. 99, 155-165 (2017) 